structural fatigue, even if fatigue was not recognized as the initial cause. Such information may be helpful in revealing areas in which further research work is needed.

\section{Regional Technical Information Services}

IN reply to a question in the House of Commons on May 12, Mr. H. Nicholls, Parliamentary Secretary to the Ministry of Works, as representing the Lord President of the Council, said that the Department of Scientific and Industrial Research was helping active local organizations to build up regional technical information services based on Birmingham, Bristol, Cardiff, Manchester and Newcastle-uponTyne, and the staffs of these centres put firms in touch with sources of information. The contact was made by actual visits from the research centres and by the normal Press reports and brochures. In answer to another question, Mr. Nicholls said that from the research reports on social and psychological research in industry, the Department, with the agreement of the Medical Research Council, had selected twelve projects as suitable for presentation in a short and popular form, and three of these had already been published by H.M. Stationery Office.

\section{International Cultural Affairs}

IN a debate on the international situation in the House of Lords on May 4, Lord Aberdare stressed the value of university scholarships and exchanges in furthering international understanding, and urged the Government to consider increasing its present grant of $£ 6,000$ a year to the European Cultural Fund which at present has an income of only $£ 32,000$ a year. Lord Lansdowne, in replying for the Government on the debate, made no comment on this proposal, which was also advanced in an adjournment debate in the House of Commons on May 1. In the House of Commons, Mr. R. Allan, the joint Under-Secretary of State for Foreign Affairs, said that the Government was playing its part in the cultural work of the Council of Europe and was anxious to take it further. It did not exclude the possibility of a further voluntary government contribution, but wished to see first what could be done from private sources, as had been suggested by Mr. H. Delargy and Mr. R. Russell in opening the debate.

\section{Beit Memorial Fellowships}

The Trustees of the Beit Memorial Fellowships for Medical Research in their report for 1958-59 announce that Sir Francis Glyn has been elected a Trustee and honorary treasurer of the Trust; that Dr. Honor B. Fell has been appointed to the Advisory Board in place of Prof. J. H. Gaddum, who retires after fifteen years service ; and that Sir Roy Cameron has been appointed secretary of the Trust in place of Prof. A. A. Miles, who retires from the secretaryship after seven years service.

The following elections have been made.

Junior Fellowships. Dr. W. D. Stein, to study the mechanism of specific transport systems across cell membranes at the molecular level, with special reference to the components concerned in the movement of glycerol across the human red blood cell membranes; at the Department of Colloid Science, University of Cambridge. Dr. G. Burnstock, to study the action of drugs on smooth muscle and the effect of autonomic nerve stimulation on the membrane potential recorded from smooth muscle cells; at the Department of Pharmacology, University of Oxford.
G. L. Asherson, to study the causation of rheumatoid arthritis, systemic lupus erythematosus and other diseases in which antibodies against human and animal tissue can be detected; at the Rheumatism Research Unit (Medical Research Council), Canadian Red Cross Memorial Hospital, Taplow. E. R. Huehns, to study the hæmoglobins and the non-hæm proteins in normal and abnormal human red blood cells, with the view of distinguishing thalassæmia from the hæmoglobinopathies; at the Department of Biochemistry, University College, London. C. T. G. Flear, to study sodium-potassium exchange in tissues during induced congestive heart failure, and its bearing on the therapy of congestive heart failure in man; at the Department of Experimental Medicine, University of Cambridge.

Fourth Year Fellowships. T. F. Slater, to continue the study of the enzymic constitution of the rat mammary gland in relation to lactation; at the Department of Biochemistry, University College, London. Dr. J. R. Tata, to continue the study of normal and abnormal pathways of metabolism of thyroid hormones; at the National Institute for Medical Research, Mill Hill, London.

\section{Presenting Science to the Public}

AN article by Prof. P. M. S. Blackett, reprinted from Progress of May 1958, appears under the title "The British Association Looks Ahead" together with two short notes on presenting science to the public in The Advancement of Science for March 1959. Prof. Blackett, starting with a brief historical survey, indicates some of the ways in which the British Association is seeking to play a wider part in the interpretation of science to the nation, and the three main aspects of modern science with which the Association must concern itself in so doing. The following note describes the work of the three area committees established at Newcastle, Durham and on Teeside, the lecture service, particularly for school audiences, the educational programme for young people under sixteen and the rapid development of the work of the Metric Committee and of the study group on the education of the graduate scientist in schools and universities. The third note describes the progress made in the preliminary survey of existing visual aids in relation to the Young People's Programme requested by the Visual Aids Committe日 in November 1958. The Young People's Programme is based on three main assumptions: that the most effective single weapon would be a magazine designed to present science attractively and authentically to young people; that it is also necessary to give the schools all possible help; and that the Science Clubs will require all possible assistance, including visual aids. It is believed that the Association would perform a major service by providing an impartial survey which outlined the role of existing agencies, published comments by those working in the field on the use and suitability of existing aids; and recommended, after consultation with existing agencies and individual experts, action to promote the better use of the materia, available as well as the production of new material.

\section{Lecture Theatre proposed for the Royal Aero- nautical Society}

The Hyde Park Corner reconstruction scheme has provided the Royal Aeronautical Society with a unique opportunity for building a much needed lecture theatre at the back of its headquarters at 